\title{
Political Realism in International Relations: Brexit and Its Implications for Nigeria
}

\author{
Odey Joseph Ogbinyi Jr., Obinna Emmanuel Okereke \\ Department of Political Science, University of Calabar, Calabar, Nigeria \\ Email: josephodey@uncial.edu.ng, emmanuelobinna550@yahoo.com
}

How to cite this paper: Ogbinyi Jr., O. J., \& Okereke, O. E. (2020). Political Realism in International Relations: Brexit and Its Implications for Nigeria. Open Journal of Social Sciences, 8, 306-320. https://doi.org/10.4236/jss.2020.810020

Received: August 25, 2020

Accepted: October 26, 2020

Published: October 29, 2020

Copyright (อ 2020 by author(s) and Scientific Research Publishing Inc. This work is licensed under the Creative Commons Attribution International License (CC BY 4.0).

http://creativecommons.org/licenses/by/4.0/

\begin{abstract}
This research addresses two issues: first, the interpretation of Brexit as a resurgence of political realism in the global system; and second, the impact of this development on Nigeria. We underscore our contention with two theories-Realism and Contagion effect-to demonstrate that the national interest of any state is what matters in international politics (UK first!); and that a lit candle can spread like wildfire in the global system (Brexit aftermath will spread to her allies, even Nigeria). The work adopts the secondary source of data collection; and is qualitative, explorative and predictive in nature. We then recommend that the Nigerian government takes advantage of Brexit to negotiate more favourable trades, and turn its focus to Nigerian aid rather than foreign aid.
\end{abstract}

\section{Keywords}

Brexit, Nigeria, Trade, Britain Economy, Realism, Europe

\section{Introduction}

Brexit is a working term used to describe the decision of Britain/UK to exit/leave the European Union (EU). EU is a politico-economic union of 28 countries that promote ease of trade and free movement of citizens between member states. Britain's membership of the EU can be traced back to her membership of the European Communities (EC), comprising the European Coal and Steel Community (ECSC), European Atomic Energy Community (EAEC) and the European Economic Community (EEC). The Treaty of Rome in 1957 by twenty-eight (28) European nations established the EC. In 1961, Britain or United Kingdom (UK) applied to be a member of the EC; and by 1973 she was granted membership into the Community. The Maastricht Treaty rather established the EU in 1993. After its formation, particularly in 2009, the EU absorbed the EC's institu- 
tions into her wider framework and the community ceased to exist. Thus, UK became a member of the EU.

The EU was set up as a leading agent of peace, an antidote to the extreme Mercantilism, nationalism or Realism which had pervaded Europe, causing bloody wars between neighbours, and which culminated in the Second World War (WW 2). EU aims to develop an internal single market through a standardised system of laws and bring about economic and political integration, cooperation and interdependence among States-for the promotion of peace, the liberalization of trade: opposing tariff barriers, domestic subsidies, sanctions and other economic tools that distort the free flow of trade and investment capital-a goal which was mutual with that of UK. The philosophical root of EU is Liberalism, a doctrine of International Political Economics, incubated by David Hume and later developed by Adam Smith in his "Wealth of the Nations". For Liberals, the goal of economic policy is to create a maximum total wealth by achieving optimal efficiency.

Nigeria's ties with Britain go a long way to her colonial experience. An outright political and economic tie! But their relationship in more recent years is economical since Nigeria has gained political independence from them. Nigeria is today a member of the British Commonwealth, and is equally Britain's second largest trading partner in Africa after South Africa, with $£ 6$ billion (about N2.4 trillion or $\$ 8.52$ billion) in bilateral trade volume by 2016 (Ukwu, 2017).

\section{Statement of the Problem}

There have been some controversies over UK's membership of the EU. Whereas no other country has attempted to leave the Union, the UK has notified the European Council of its plans to withdraw from the union. A referendum was passed on the 23rd of June 2016-the United Kingdom European Union (UK-EU) membership referendum - whether to remain a member of the EU or to withdraw from the Union. And $51.9 \%$ of the valid votes were in favour of the withdrawal (https://en.m.wikipedia.org/wiki/Causes of the vote in favour of Brexit). This is a resemblance and a recurrence of, as well as a contrary result of an earlier referendum in 1975, championed by the Labour Prime Minister Harold Wilson, on the UK's continuous membership of the then EU. Then, $66 \%$ voted "yes" to stay in the then EU (Trueman, 2016). In early 2019, Theresa May the Prime Minister (PM) of Britain reactivated Article 50, a plan for any country that wishes to exit EU. And March 29, 2019 was set as the date for the agreement to be reached. But for this to fall through, it must be approved by British Members of Parliament (MPs). These MPs rejected the proposal [which they claimed did not recover UK's sovereignty from EU] and frustrated May long enough for her to step down as PM. Boris Johnson is now the new PM as he continues to renegotiate a more favourable withdrawal agreement that the MPs will approve. There is even a possibility of a "no-deal Brexit" i.e. a Brexit without a withdrawal deal, this can have dire political and economic consequences for UK in the future! 
Brexit has implications which suggest a resurgence of Political Realism-this is contrary to the Liberal undertones of the EU. Brexit favours economic nationalism, mercantilist doctrines of protectionism, an emphasis on national interest over international interest. Analysts argue that this will distort the harmony and peace that was sought for in the EU. It may yet have economic implications for other states. Indeed, the current economic changes flowing from the decisions of Britain will not go unnoticed globally, especially among her large political or economic allies or her descended populations, particularly Nigeria-as shall be the focus of this study.

\section{Method/Approach}

This study is:

- Qualitative; it gives no consideration to statistical and mathematical data, but examines, explains and interprets data collected and collated from secondary sources-as proof to Brexit as a realist undertone, and that its implications on Nigeria.

- Causal; the study is also concerned with determining the possible causes of Brexit as well as the effect relationship.

- Philosophical and Exploratory; in that it reveals the comprehensive system of beliefs, the general outlook and the principles related to political realism.

- A Case study research; It is equally a case study of the Brexit event, using the exploratory, cumulative and critical instance case study forms. It is exploratory in that it provides knowledge about the conditions that necessitated Brexit; as well as the conditions which will cause Brexit to have an effect on Nigeria. As a cumulative case study, it sites examples of the past occurrences of the contagion, leading to an expectation of its re-manifestation in the Brexit issue.

- Adopts a systematic review of materials; the literature review is rather a synthesis of the polemics relevant to the understanding of brexit as a manifestation of realism.

- Predictive; since some of the forwarded effects of Brexit on Nigeria are yet to come. Most Commentators on the subject are positive about most of these effects coming to fruition.

\section{Sources of Data}

The major source of this investigation is the secondary data collection method

- Articles about the history of the European Union and Britain's membership of the Union; about Brexit and the conduct of referendum in Britain, the impact of Brexit on Nigeria.

- News updates on Brexit, the causes of Brexit, and its effects on UK.

- Texts on international relations and the two central perspectives related there in: liberalism and realism; on research methodology.

- Journal articles on realism in international relations; and Brexit as a resurgence of (political) realism. 


\section{Theoretical Perspectives}

Political Realism is sometimes referred to as real politik or power politics. Other related terms are mercantilism, economic nationalism, statism or protectionism. As a school of thought, it explains international relations in terms of Power. Its roots can be traced back to the ancient writings of inter alia the Greek historian Thucydides in his "The Peloponnesian Wars" (around 431-404 BC), the Chinese scholar Sun Tzu in his magnum opus "The Art of War", the Hindu statesman and philosopher Kautilya (around $300 \mathrm{BC}$ ), and in modern era-the likes of Thomas Hobbes in his analysis of the State of nature, Hans Morgenthau in his six (6) principles of Realism, and Henry Kissinger. At the core of the realist paradigm is a belief in the primacy of the superstructure over the substructure (politics over economics); national security issues referred to as "High Politics" over economic, cultural and domestic issues referred to as "low politics". An emphasis on a state's protection of its own vital interest, political independence, and territorial sovereignty, at all cost (even to the point of going to war). Realists argue that "military power" is often the necessary ingredient for national survival-a weakness of which the survival of such a state is jeopardized. In this way, the rise and/or fall of states in their bid to exist resembles Charles Darwin's theory of natural selection i.e. "struggle for existence", or as Herbert Spencer has it "survival of the fittest". The core assumptions are:

- Statism: In the global system, states or nation states are the key or most important actors. Realists believe that nation states are the main actors in international politics. As such it is a state-centric theory of international relations. This contrasts with liberal international relations theories which accommodate roles for non-state actors and international institutions. Therefore Power is the most important concept in explaining as well as predicting the behaviour of states. Staism holds a pessimistic view of Human nature. Humans are therefore seen as inherently selfish and bad, "poor, nasty, short and brutish" as Hobbes assumes in his "state of nature".

- International economic relations between states are competitive and conflictual-a struggle for power where nations inevitably rely on their own capabilities for survival. There are gradations of capabilities among states-since the existing conditions of comity of nations show that there are greater states and lesser ones.

- There is a direct relationship between the pursuit of political power and economic wealth. Wealth is absolutely an essential means to Power [whether for security or for aggression]. And power is essentially a means to the acquisition or retention of wealth. They are both the ultimate ends of national policy (Viner, 1958).

- Mercantilists argue that for a state to develop, the government must play a major role through protectionist policies-economic policy of restraining trade between countries through methods such as tariffs on imported goods, restrictive quotas, and a variety of other government regulations-to pro- 
mote the increased wealth of the nation.

- States are unitary rational actors. They are self centred and their decision-making processes are guided by choices to maximize their own benefits and protect their own national interests rather than global interests.

The Contagion Effect is our other theory. It will aid our understanding of why and how Brexit can affect Nigeria. As a model, Contagion Effect explains that there is a possibility of the spread of market changes or disturbances from one regional market to others; a diffusion of either economic booms or economic crises throughout a geographic region as a result of global market interdependence. In economics and finance, a Contagion can be explained as a situation where a shock in a particular economy or region spreads out and affects other economies or regions by way of price movements (increase or decrease).

The phenomenon has been functionally evident in history but the term "Contagion" first emerged during the 1997 Asian financial markets crisis when the Thai baht collapsed and market shocks quickly spread to nearby East Asian countries, resulting in widespread currency and market crises in the region. The term "contagion" was coined by researchers who began to investigate how previous financial crises spread across national borders. Some of the instances of Contagion surfaced in 1825, a banking crisis that originated in London in the Bank of England sparked a stock market crash that later spread to the rest of Europe and eventually Latin America. The contagion effect in an integrated global economy is also exemplified in the global Great Depression of 1930 caused by the 1929 US stock market crisis.

It is important to note that Contagions are more likely to occur among developing countries or emerging markets; and is often exacerbated by "asymmetric information". Asymmetric information, sometimes referred to as "Information failure" is present whenever one party to an economic transaction possesses greater material knowledge than the other party. This normally manifests itself when the seller of a good or service has greater knowledge than the buyer, and possibly vice versa. This is to say that larger and more established markets are better able to deal with financial contagions than developing economies. For instance, despite neighboring most of the Asian countries afflicted during the 1997 crisis, China's markets remained unscathed.

The advocates of this theory hold a few assumptions:

- Contagions can occur both globally and domestically. In a domestic market, it can occur if one large bank sells most of its assets quickly and confidence in other large banks drops accordingly. The failure of Lehman Brothers in the United States is an example of a domestic contagion. And globally, it can result in quick crashes of closely correlated regional currencies, as in the 1997 crisis.

- With increasing interdependence and correlation between economies, the possibility of contagion has increased. It can spread speedily and unexpectedly.

- The fundamental underpinning of the contagion scenario where price 
movements in one market are resultant of shocks or volatility in the other market is that there is a perfect information flow.

- Usually associated with a financial crisis, contagions can be manifested as negative externalities diffused from one crashing market to another.

(Bennett, Coleman, \& Co. Ltd., 2017; Investopedia, 2017b: Contagion; Investopedia, 2017a: Asymmetric Information).

\section{The Origins of Brexit}

Dennison and Carl (2016: p. 1) write that there are more remote causes to the Brexit vote other than the immediate causes (Xenophobia, and dissatisfaction with Britain's EU membership) presented by many analysts. They explain further that first, the UK is the least well-integrated EU member state; essentially the least European country, and has a comparatively less European self-identity and lower trust in the EU. This is a fact that stems from certain historical features, namely: UK is the only allied European power not to have been occupied during the Second World War (WW2); it has its own common law legal system, which contrasts with the civil law system of continental Europe; it has an established church which caused most British Christians to owe their allegiance to a national institution headed by the monarch, rather than to an international institution headed by the Pope; and that Britain is an island whose surrounding waters have partially isolated it from cultural developments on the continent. Another remote cause of the vote is the rise in EU immigration, which began in the late 1990s, and the Eurozone debt crises, which precipitated mass unemployment across Southern Europe.

For Riley \& Ghiles (2016: p. 1), Brexit was influenced by a series of extremely damaging blows: the economic crisis of 2008; the self-inflicted damage from failure to deal with the flaws of the euro following the crisis; Russian success in upsetting the post-cold war balance of power in Europe; terrorist attacks from ISIS and immense migration flows into the Union. They also consider that Britain's history differs from that of its European neighbours: Its position as an unconquered island nation, a long tradition of parliamentary democracy and an ingrained sense that ultimately it can look after itself, marks it out from other European nations. UK was never that sympathetic to the European ideal but only joined rather because there did not seem to be any other option than joining the then more prosperous Western European democracies.

Other open sources such as Wikipedia provide the major causes of Brexit vote as "Sovereignty" and "Immigration" issues. The first factor follows from data collected and collated from the polling team of Lord Ashcroft, who questioned 12,369 of the voters of June 23, 2016 referendum. This poll showed that about $49 \%$ (nearly half) of the "leave" voters said the biggest single reason for wanting to leave the EU was "the principle that decisions about the UK should be taken in the UK." The second factor also follows from the same poll. It uncovered that One-third (33\%) of leave voters said their main reason was that leaving offered 
the best chance for the UK to regain control over immigration and its own borders.

\section{Impact of Brexit on UK}

The analyses of Dhingra et al. (2016: p. 1) give EU away as the largest trade partner of UK, where about a half of the UK's trade lies with the Union. Britain's EU membership has reduced her trade costs resulting in cheaper goods and services for consumers and allowing businesses to export more. [This is a benefit gained by not just the UK, but also other member countries]. There is also a customs union between EU members, which means that all tariff barriers have been removed within the EU, allowing for free trade in goods and services. All these result from the EU's continuing efforts to create a single market within Europe.

The above prompts a question with the contending issue: What are the economic consequences of Brexit on UK's trade? Ibid, Dhingra et al. assert that the effects will depend on what policies the UK adopts following Brexit; but also state that there is uncertainty as to the future of UK-EU relations after Brexit. This gives room to two possibilities: optimistic and pessimistic possibility. In the former, it is assumed that in a post-Brexit world, the UK will enjoy like Norway that is a member of the EEA but not a full member of EU market integration programmes. For one, Norway enjoys a free trade agreement with the EU. As a member of the European single market, Norway also adopts policies and regulations designed to reduce non-tariff barriers within the single market. In the latter, apologists argue that the UK will fail in negotiating a new trade agreement with the EU; therefore UK-EU trade following Brexit will be governed by World Trade Organisation (WTO) rules. This implies larger increase in trade costs like higher tariffs on imports, and higher non-tariff barriers to trade (arising from different regulations, border controls, etc.). The UK may not participate in future steps that the EU takes towards deeper integration and the reduction of non-tariff barriers within the EU. Brexit would lower UK living standards.

According to Irwin (2015: p. 6) the following are the impacts of Brexit on UK: The UK becomes less attractive as a gateway to Europe, as a base for corporate Head Quarters, and as a location for investment from Europe. The UK loses influence over EU regulation without gaining much freedom to regulate independently. The UK gains flexibility over industrial policy, but loses the benefits from scale and influence. UK will find it harder to resolve trade disputes. And that the UK will lose the benefit of being able to influence both in and through the EU, impacting on economic and foreign policy interests.

Brexit also has possibilities for EU itself. According to Riley and Ghiles (2016: p. 1), Brexit "may well mark the beginning of the end of the EU as we have known it". Ibid, they argue that "the process of British exit from the Union is likely to fragment Union solidarity, opening up fissures that will be difficult to close". 


\section{Causal Interpretations of Brexit in Relations to Political Realism}

Brexit put the world in frenzy. It crushed the dreams of those who have come to believe in the power of international institutions, the philosophy of neoliberalism-which believes that institutions ensure cooperation between states through a shared commitment to rules, values, and norms, and that they have the ability to mould states into certain patterns of behavior.

As Woron (2016) has it, "for realists, Brexit was no surprise!”. Neorealists have ultimately argued that international institutions are ultimately not that influential; and that these institutions cannot actually force states to comply with international rules and to act contrary to their own national interests. With the emergence of Brexit, one should now be so quick to pass judgment: the establishment and expansion of institutional frameworks which gave liberalists an edge in their contentions can now be rejected.

Brexit has demonstrated as Woron (2016: p. 2) puts it that institutions ultimately have no real coercive power, because it is entirely possible and quite easy for a state to simply pull out and walk away if it does not want to follow an institution's rules. This undoubtedly comes as a blow to the neoliberal hopes that many have come to entertain. Ibid, Woron describes Brexit as so shocking and upsetting precisely because it suggests that institutions may indeed be as fragile as realists have warned, as exemplified in the speeches of the Polish foreign minister who declared that Brexit showed "declining trust in the EU," and Turkey's prime minister who tweeted that "the EU's disintegration has started". Furthermore, he asserts that Brexit serves as proof for some of realists' most repeated dictums: those forces, such as nationalism and the desire for autonomy, are ultimately more influential in state affairs. The significance of the force "Nationalism" has two components: first, the idea that people are divided into particular nations, based on things like a homeland, common culture, shared values, and a shared past; and second, the idea that each nation should have its own autonomous political state, with which it can make its own decisions and effectively enact its own laws. Both components of nationalism are indeed apparent in the Brexit decision.

For Oliver (2017: p. 2), "the power that Britain or the EU has in Brexit is therefore shaped by structural factors such as material capabilities, wealth or military power and how decision makers use them". Material capabilities, wealth or military power are the major emphasis of realists. He further interprets the nature of the organization (EU) - which asks states to surrender control of their national policies in exchange for access to a single currency and economic market-as a peculiarly anti-democratic organization particularly for one that lists democracy among the preconditions for membership. Thus, as Zacharycblog (2016: p. 1) interprets, Brexit could be that another state (Britain) has seen its interests subsumed by a larger power (EU) and consequently wishes to break free; or a foolish move in an anachronistic system of power. He further contends 
that UK's participation is heavily contingent upon the benefit it acquires from the European Union, and a fracturing of that union can only come from dissatisfaction because it is considered as impinging on things like British sovereignty, a fact which uncovers realist undertones.

\section{Nigeria, Britain and the Impact of Brexit on Nigeria}

At this juncture, a restatement from the background of the study is unavoidable. Nigeria's ties with Britain goes a long way to her colonial experience, era. An outright political and economic tie! But their relationship in more recent years is economical since Nigeria has gained political independence from them. Nigeria is today a member of the British Commonwealth, and is equally Britain's second largest trading partner in Africa after South Africa, with $£ 6$ billion (about N2.4 trillion or $\$ 8.52$ billion) in bilateral trade volume by 2016 (Ukwu, 2017). In fact, as Hile (2016) reports, the Data from the National Bureau of Statistics shows that the UK was Nigeria's largest source of foreign investment in 2015. With this in mind therefore, it is not farfetched that the contagion effect follows Brexit to Nigeria.

Brexit decision is fraught with economic, political, immigration and diplomatic implications that would spread far beyond its borders. Their breakdown follows thus:

Economic Impact; This has other strands as follows:

- Currency devaluation and a crash in the price of UK imported goods and assets: This is non-debatable because what devaluation of a country's currency ideally does is to reduce the price of its exported goods. For Emewu (2017: pp. 2-3), some of the wider impacts of Brexit have started manifesting. For one, the British pound sterling fell against major currencies, including the Nigerian naira on the day the result of the referendum was announced, the pound sterling exchanged for N386.26 at the interbank market, a significant fall from N414.70 it exchanged the previous day. The implication, experts believe, is that goods and services from the United Kingdom may be cheaper for Nigeria as it has introduced volatility in the market place, leading to huge crash in prices. There are speculations that it will affect all assets prices in the UK.

- Market instability and a drop in Investment: Because Brexit has made UK's and its allies' Market unstable, Nigeria as a UK ally may not see an inflow of investors just yet because of risk sensitivity that has developed from Brexit. Most investors have become extremely worried, and have begun to look for a safe haven (more stable markets) for their assets. Hile (ibid) further reports a slowing British economy and its reverberating effects could signal a drop in investment, trade, and also remittances from the Nigerian in Diaspora who sent home $\$ 21$ billion in 2015. For Ukwu (2017) the Gross Domestic Product (GDP) of the United Kingdom would shrink over time and a weaker and smaller UK economy would scale back its investment in devel- 
opment projects in Nigeria. As well, Nigeria would no longer be offered full access to the lucrative EU market. [N/B: Trade agreements between EU countries and non-EU countries are negotiated by the European Commission].

- Loss of free trade benefits: With the event of Brexit, Nigeria may not be able to enjoy its previous privilege of a free trade tariff from EU which she gained through her access to Britain.

- Renegotiation of conditions of trade: The Bilateral trade between Nigeria and the UK, currently valued at $£ 6$ billion (about $\$ 8.3$ billion) and projected to reach $£ 20$ billion by 2020 , will be disrupted as trade agreements made under the auspices of the EU have to be renegotiated, especially at a time when the Nigerian government is trying to fix an economy on the brink of a recession by removing subsidies.

\section{Immigration Impact:}

Once Brexit is fully implemented, Nigerians living in the UK, as well as those hoping to go to the UK will be concerned about their status. What would immigration policy look like in post-Brexit UK? Controls may become tighter; or in order to boost trade relations with Nigeria, the UK could make immigration for Commonwealth citizens slightly easier, especially as IMF predicts that by 2019 the Commonwealth will contribute more to the world's economic output than the EU. Ukwu (2017) also supports this view asserting that it would foster anti-immigration which will affect Nigeria who has a large population of its citizens in Diaspora. Ukwu also expects that Britain will be very strict on visa applications especially from countries like Nigeria which has larger visa applicants to the UK.

\section{Political implication:}

Brexit may heighten nationalistic pressures among Nigeria's disparate ethnicities. In fact, it has fuelled secessionist sentiments in Nigeria. In line with the concluded Brexit June 23, 2016 referendum, the Indigenous People of Biafra (IPOB), an Igbo South-East sect agitating for an independent state of Biafra, has launched a campaign slogan, "Biafrexit", to give a fillip to their cause. In fact, the Spokespersons of IPOB, Mr Emma Nmezu and Dr Clifford Chukwuemeka Iroanya, applauded Brexit in their speech following the "leave vote". They said, "The Indigenous People of Biafra congratulates the government and people of Britain for organising the Brexit vote and applauds the British government for respecting the wishes of her citizens" (Hile, 2016; Ukwu, 2017). Therefore, Brexit is a signal that political unions can no longer be seen as self-perpetuating, ultimate.

\section{Security implication:}

Ajasa (2016) argues beyond trade, politics and immigration. He believes that since the UK is a key partner in Nigeria's security, it has been crucial to drawing international attention to the Boko Haram insurgency in Nigeria's northeast. The effect of Brexit is that the UK would become distracted from this security 
threat.

\section{Realist Debates}

The collapse of the European empire marked the emergence of states, as well as the emergence of realist doctrines (Edame, 2010: p. 118). Britain, like most European states then began to pursue policies of "economic expansion" and "power accumulation" in order to attain a hegemonic position among other states. This was often achieved through both political and economic wars against rivals, a show of military might and an adoption of trade restrictions (quota, embargo, tariffs) - the key components of Realism. But by the end of the 18th century, realist ideas had become weak, the horrors of war and the conspicuous disadvantages of trade restrictions had began to play out. Most states soon joined the league of states advocating for collective interest, cooperation and coexistence in order to revamp their economy and rehabilitate lost infrastructure. The alternative way for Britain to continue surviving would be to join the then European communities (EC). The available had become the desirable.

Britain, having recently opted to leave the EU divulges that $a b$ initio she did not join the Union because she found solace in the neoliberal doctrines of self-perpetuating institutions, but because of the fact that she had lost her place as a hegemonic power among other states. The implication of joining the EU was that Britain is expected to operate within the provisions of the treaty of the Union. UK then became equal with other member states, since in theory, International Organisations (IOs) create a platform for the equality of states, thereby debunking the realist belief in the existence of a hierarchy, gradations of capabilities in the comity of nations. EU laws have a way of dictating or limiting the domestic laws of member States; for in the presence of a particular EU legislation, member states may often need to forgo their own municipal laws. Such legislations can limit the national sovereignty of member states. In fact, EU laws did not only dictate the national sovereignty of Britain but also its immigration policies. Britain was dissatisfied with this arrangement; EU laws could no longer protect its national interest. Both issues of sovereignty and immigration are vital in Britain's national interest. That is why most commentators, like Dennison and Carl, Hile etc name them as the major causes of the $51.9 \%$ vote in favour of Brexit. Furthermore, UK also sought to protect its territorial borders from potential threats, and Britons were xenophobic of immigrants, blaming them for their economic problems which were already being contained through various austerity measures.

One import from this therefore is that public opinion in Britain supports that lawmaking for the country, and the control of migrants and national borders be decided within the country and by their own countrymen (government). This backs up the position of classical realists that the behaviours of individual citizens (who are inherently self-centered) of a state are what manifests in that state's relations outside its boundaries. Another import is that States are 
actually the most important actors in the international system. Importantly, international relation does not occur in a vacuum; not even within any platform of international organisation but within a state. An escapade by one state (UK) can affect the operation of an international organisation (EU). It is indubitable that Brexit will affect trade relations between UK and even the EU. UK is undeniably the largest trading partner of EU where it holds half of its trade deals with the Union. The tension will of course take away the economic benefits enjoyed by Britain since future cooperation cannot be guaranteed. In fact, the possibility of EU refusing to trade with UK after the materialization of article 50 is expected, because both of them no longer have a mutual goal. This also manifests realist undertones.

It may now be trite to say that Nigerian-Britain relations can be traced back to her colonial era. That argument can however be sustained. Wikipedia submits that since independence, Nigeria has maintained favourable relations with the UK. Nigeria's former speaker of the House of Representatives, Hon. Dimeji Bankole stated in contra, that Nigeria's trading relations with the EU, including the UK, was not always straightforward and not always in Nigeria's favour (https://www.thisdaylive.com/index.php/2016/10/06/bankole-calls-for-strongertrade-relations-between-nigeria-britain/). Other than the obvious sense in this statement-that Nigeria is being exploited in the partnership, we can deduce further that a Nigeria-UK partnership is a Nigeria-EU partnership. This is so because UK trades with EU, and Nigeria with the UK. That is, Nigeria indirectly trades with the EU since the benefits/detriments of UK-EU trade relations indirectly affect her. The friend (EU) of Nigeria's friend (UK) becomes Nigeria's friend. EU and Nigeria share a mutual Friend (UK). For instance: although she is not a member of the EU, Nigeria benefits from duty free access to the EU Single Market for goods. Second, the British pound sterling fell against Nigeria's naira on the day the result of the Brexit referendum was announced [from \#414.70 per dollar to \#386.26 per dollar].

What does UK sell/offer that Nigeria would consider partnership a necessity, or vice versa? Let us consider that the UK is versatile with architecture, digital technologies and professional services such as cyber security, and general consultancy services; academia, healthcare, renewable energy, Oil and Gas and mining supply chain. Such a partnership would aid Nigeria achieve its huge economic potentials; benefit from their skills and technology transfer, economies of scale and access to innovative technologies. Nigeria will also benefit from their urban planning and transportation networks. The UK is also a leading investor in Nigeria, which is of course facilitated by her reputation as the biggest economy in Africa, and 26th in the world in terms of Gross Domestic Product (GDP) (Olaiya, 2015). As a matter of fact, many of their companies operate in Nigeria, in banking, telecoms and technology, consumer goods, and of course in the energy sector, E.g. GlaxoSmithKline (GSK). Let us not forget in a hurry that both countries share a common language: English. Nigeria stands a chance of losing the above benefits if article 50 scales through. She 
may well find herself in the same boat as post-Brexit UK, losing trade preferences to the EU market altogether. Another possibility is that it could spur Britain to build stronger, reciprocal trading relations with Nigeria, a call which Bankole advocates. According to him, "there are strong, pragmatic reasons indeed, for both Nigeria and the UK, to start discussing a new, post-Brexit trade deal." (https://www.thisdaylive.com/index.php/2016/10/06/bankole-calls-for-strongertrade-relations-between-nigeria-britain/). This subject of establishing stronger partnership deals between Nigeria and the UK was also tabled by the economic forum of both countries as organised by the Nigerian London Business Forum (NILOBF) in 2015. There is a conviction that posterity holds good tidings and benefits for both countries. Thus, Brexit could be beneficial to Nigeria.

\section{Conclusion and Recommendations}

To make sense of Brexit as a manifestation of realism, one must first understand the circumstances which qualify any occurrence as having a realist undertone. The work submits to the fact that UK prefers to pursue national interest over the interest of the European Union. While staying in the EU was based on economic self-interest, the case to leave by UK was mainly centered on two other things: the desire to restrict immigration, and a greater desire to recapture her lost place (hegemonic position) in the world. These of course have realist concerns. Furthermore, we conclude that by virtue of the interdependence of the EU, Britain and Nigeria, economic movements (booms or crisis) will spread in each other's markets. The more tangible impact of Brexit on Nigeria is as presented namely: economic implications in terms of market instability and a drop in foreign investment, loss of trade benefits, renegotiation of conditions of trade; political implications as in aggravating nationalist tensions (IPOB, MASSOB), diplomatic relations and foreign policy tensions and frictions; and immigration concerns in terms of strict visa application policies; and security concerns for the fight against terrorism in Nigeria.

- The Government of Nigeria can take advantage of Brexit to make more favourable terms of trade with Britain. The issues of devalued currencies and balancing of trades in imports and exports must be addressed even as a post-brexit era may warrant it.

- As Oriloye (2016: 110-111) advises, Nigeria should reduce her dependence on UK for aid. She should diversify her economy and aid herself from within. One way to do this is to ensure a conscious and concerted effort by both the public sector and private individual business tycoons to develop strategies that will solve Nigeria's economic problems via Nigeria aid rather than foreign aid.

- In the short term, Brexit may be hard-hitting on Nigeria's developmental trajectory, however, with proper planning and redirection, a new cause may mean progress for Nigeria

It is also conclusive that the fears of yesteryears are back. The self-perpetuating institutions projected by neoliberals have failed as realism or mercantilism re- 
surges in the international system with the event of Brexit. Mention must be made that this example is not exhaustive seeing the escapade of North Korea in recent years, testing intercontinental ballistic missiles (IBM) incessantly, is deeply affecting the self-perpetuating United Nations. The recent Xenophobic attacks in South Africa which many commentators argue stem from a fear of domination and the need to reclaim control of her economy that has been hijacked by aliens also has realist undertone. We will not exclude President Donald Trump's decision, in 2017, to cease all participation in the 2015 Paris Agreement on Climate change mitigation in on the grounds that the deal was not fair to the United States. What more can we say? "Self-preservation, not Love, is the strongest force on earth!" A second conclusion that can be drawn here is that the next Contagion analysis will add Nigeria to its tally.

\section{Conflicts of Interest}

The authors declare no conflicts of interest regarding the publication of this paper.

\section{References}

Ajasa, F. (2016). Brexit: How will it affect Nigerians? http://www.vanguardngr.com/2016/06/brexit-will-affect-nigerians/

Bennett, Coleman \& Co. Ltd. (2017). Definition of Contagion. https://economictimes.indiatimes.com/definition/contagion?from $=\mathrm{mdr}$

Dennison, J., \& Carl, N. (2016). The Ultimate Causes of Brexit: History, Culture and Geography. https://blogs.lse.ac.uk/politicsandpolicy/explaining-brexit/

Dhingra, S. et al. (2016). The Consequences of Brexit for UK Trade and Living Standards (No. 2). Centre for Economic Performance (CEP), London: London School of Economics and Political Science (LSE).

Edame, G. E. (2010). Development Economics and Planning in Nigeria (pp. 118-119). Calabar: Favoured Trust Limited.

Emewu, I. (Ed.) (2017). BREXIT Aftermath: How It Affects Nigeria. http://sunnewsonline.com/brexit-aftermath-how-it-affects-nigeria/

Hile, M. (2016). Potential Impact of Brexit on Nigeria. http://www.financialnigeria.com/potential-impact-of-brexit-on-nigeria-updated-featur e-58.html

Investopedia (2017a). Asymmetric Information. http://www.investopedia.com/terms/a/asymmetricinformation.asp

Investopedia (2017b). Contagion.

Irwin, G. (2015). Brexit: The Impact on the UK and EU. London: Global Counsel.

Olaiya, T. T. (2015). Strengthening Nigeria-UK Trade Relations. https://m.guardian.ng/features/focus/strengthening-nigeria-uk-trade-relations/

Oliver, T. (2017). Theory and Brexit: Can Theoretical Approaches Help Us Understand Brexit?

https://blogs.lse.ac.uk/brexit/2017/03/14/theory-and-brexit-can-theoretical-approaches -help-us-understand-brexit/

Riley, A., \& Ghiles, F. (2016). Brexit: Causes and Consequences. 
https://www.cidob.org/es/publicaciones/serie de publicacion/notes internacionals/n1 $159 /$ brexit causes and consequences

Trueman, C. N. A. (2016). A History of the European Union and Great Britain. http://www.historylearningsite.co.uk/british-politics/a-history-of-the-european-unionand-great-britain/

Ukwu, J. (2017). 7 Potential Impact of Brexit on Nigeria [LIST].

https://politics.naij.com/870440-top-7-effects-of-uks-eu-exit-on-nigerian-visa-applican ts-and-investment.html

Viner, J. (1958). Stability and Progress: The Poorer Countries' Problem. In D. Hague (Ed.), Stability and Progress in the World Economy (pp. 41-65). London: Palgrave Macmillan. https://doi.org/10.1007/978-1-349-08446-3 4

Woron, F. (2016). For Realists, Brexit Was No Surprise.

Zacharycblog (2016). Realism and Brexit. https://zacharycblog.wordpress.com/2016/04/28/first-blog-post/ 